JPM (Jurnal Perak Malahayati), Vol 3, No. 2. November 2021,

E:ISSN 2684-8899 (Online) P:ISSN 2685-547X (Cetak), Hal 109-112

\title{
PENYULUHAN TENTANG INOVASI BUAH ALPUKAT DAN MADU UNTUKMENCEGAH RESIKO KETIDAK STABILAN TEKANAN DARAH PADA PENDERITA HIPERTENSI DI DESA HANURA KEC. TELUK PANDAN KAB. PESAWARAN
}

\author{
Ike Ate Yuviska ${ }^{1}$, Susilawati $^{2}$ \\ ${ }^{1,2}$ Program Studi Kebidanan Universitas Malahayati \\ Email: ikeyuviska12345@gmail.com \\ susilawati@gmail.com
}

\begin{abstract}
ABSTRAK
Penyakit hipertensi merupakan penyebab umum tejadinya stroke dan serangan janutung. Hipertensi dapat disembuhkan dengan mengkonsumsi obat herbal, salah satunya adalah alpukat dan madu. Kandunganbuah alpukat adalah MUFA (monounsatured fatty acid) yang berperan untuk menurukan kadar trigliserida dan kolestrol LDL darah yang tinggi. Kandungan yang lain yaitu niasin yang berperan untuk meningkatkan kolestrol HDL. Madu mengandung assetilkolin yang berfungsi untuk melancarkan peredaran darah dan menurunkan tekanan darah. Tujuan penelitian ini untuk mengetahui pemberian jus alpukat dan madu terhadap penurunan tekanan darah pada lansia penderita hipertensi.

Kegiatan telah dilaksanakan pada hari Senin, 29 maret 2021. Subjek dalam penelitian ini adalah lansia di desa hanura kec. Teluk pandan kab. Pesawaran. Kegiatan dilakukan dengan memberikan edukasiberupa penyuluhan dengan metode ceramah. Waktu yang diperlukan dalam penyampaian materi adalah 40 menit. Terdapat peningkatan pengetahuan lansia terhadap pemberian jus alpukat dan madu untuk menurunkan tekanan darah pada lansia penderita hipertensi.

Kata kunci : jus alpukat, lansia, hipertensi
\end{abstract}

\section{ABSTRACT}

Hypertension is a common cause of stroke and heart attack. Hypertension can be cured by consuming herbal medicines, one of which is avocado and honey. The content of avocado fruit is MUFA (monounsatured fatty acid) which plays a role in reducing high blood triglyceride and LDL cholesterol levels. Another content is niacin which plays a role in increasing HDL cholesterol. Honey contains acetylcholine which functions to improve blood circulation and lower blood pressure. The purpose of this study was to determine the provision of avocado juice and honey to reduce blood pressure in elderly people with hypertension.

The activity was held on Monday, March 29, 2021. The subjects in this study were the elderly in the village of Hanura, kec. Pandan bay district. Offer. Activities carried out by providing education in the form of counseling with the lecture method. The time required to deliver the material is 40 minutes. There is an increase in the knowledge of the elderly about giving avocado juice and honey to reduce blood pressure in elderly people with hypertension.

Keywords : avocado juice, elderly, hypertension 


\section{Ike Ate Yuviska, Susilawati}

\section{PENDAHULUAN}

Seiring dengan bertambahnya usia maka tekanan darah akan bertambah tinggi, karena pada lansia terjadi perubahan pembuluh darah yang menyebabkan hipertensi. Misalnya, sifaselastis dari pembuluh darah menjadi berkurang dan dinding pembuluh darah Arteri menjadi kaku,sehingga menyebabkan penyempitan dari pembuluh darah dari pembuluh darah serta aliran darah kejaringan dan organ-organ tubuh menjadi berkurang. Berkurangnya sel-sel ginjal akibat proses menua menyebabkan kemampuan ginjal untuk menyaring zat-zat yang melewatinya berkurang, sehingga dapat menyebabkan hipertensi (Gray et al.,2005).

Menurut kemeskes RI hipertensi merupakan gangguan aliran darah yang menyebabkan kenaikan tekanan darah diatas normal yaitu 140/90 mmHg. Organisasi kesehatan didunia WHO menetapkan hipertensi sebagai factor resiko nomor tiga penyebab kematian didunia setelah stroke dan tuberculosis, yaitu mencapai $6,7 \%$ pada populasi pada semua umur di Indonesia ( Kementrian Kesehatan RI,2010. Hipertensi penyebab kematian nomor tiga. Kementrian Kesehatan RI, 2010.

Berdasarkan data WHO tahun 2007 dari 50\% penderita hipertensi yang di temukan hanya $25 \%$ yang mendapat pengobatan, dan hanya $12,5 \%$ yang diobati dengan baik (adequately treated cases). Hipertensi merupakan penyakit yang pada umumnya tidak tergejala, sehingga pasien tidak merasakan keluhan. Pasien juga tidak memahami bahaya laten yang tersembunyi dibalik penyakit hipertensi sehingga mereka menganggapi dan penting untuk meminum obat secara teratur. Selain itu factor ekonomi juga dapat menjadi salah satu penghambat bagi penderita hipertensi melakukan pengobatan. Karena butuh biaya yang tidak sedikit untuk melakukan pengobatan. Pada hal resiko yang akan timbul jika terjadi komplikasi atau serangan penyakit kardiovaskuler lainnya akan lebih mahal dibandingkan dengan meminumobatsecara rutin (Pfizer Indonesia, 2007. Mengapa Hipertensi dan Hiperkolestrol Harus Diobati. Pfizer Indonesia, 2007

Intervensi inovasi yang digunakan sesuai dengan penelitian Mia Jiandita, 2011 yang berjudul "Pengaruh Pemberian Jus Alpukat Dan Madu Terhadap Penurunan Tekanan Darah Pada Lansia Penderita Hipertensi di Posyandu Edelweiss Dusun Serut Palbapang Bantul Yogyakarta” . Selain Mengunakan Jus alpukat dan Madu Meurut Evizar, dkk tahun 2021 penurunan hipertensi bisa dengan mengkonsumsi Jus Semangka, akan tetapi dalam penurunan hipertensi kita mengunakan jus alpukat dan madu.

Dengan melihat fenomena diatas dan belum diketahuinya pengaruh pemberian jus alpukat dan madu terhadap penurunan tekanan darah pada lansia penderita hipertensi di Desa hanura Kec.Teluk PandanKab.Pesawaran tahun 2021. 


\section{MASALAH}

Di Desa Hanura Kec. Teluk Pandan Kab.Pesawaran kegiatan ini dilakukan atas dasar belum adanya program edukasi kepada masyarakat tentang pentingnya mencegah hipertensi dengan buah alpukat dan madu.Tujuan Kegiatan ini adalah meningkatkan pengetahuan dan pemahaman kepada masyarakat tentang mencegah hipertensi.

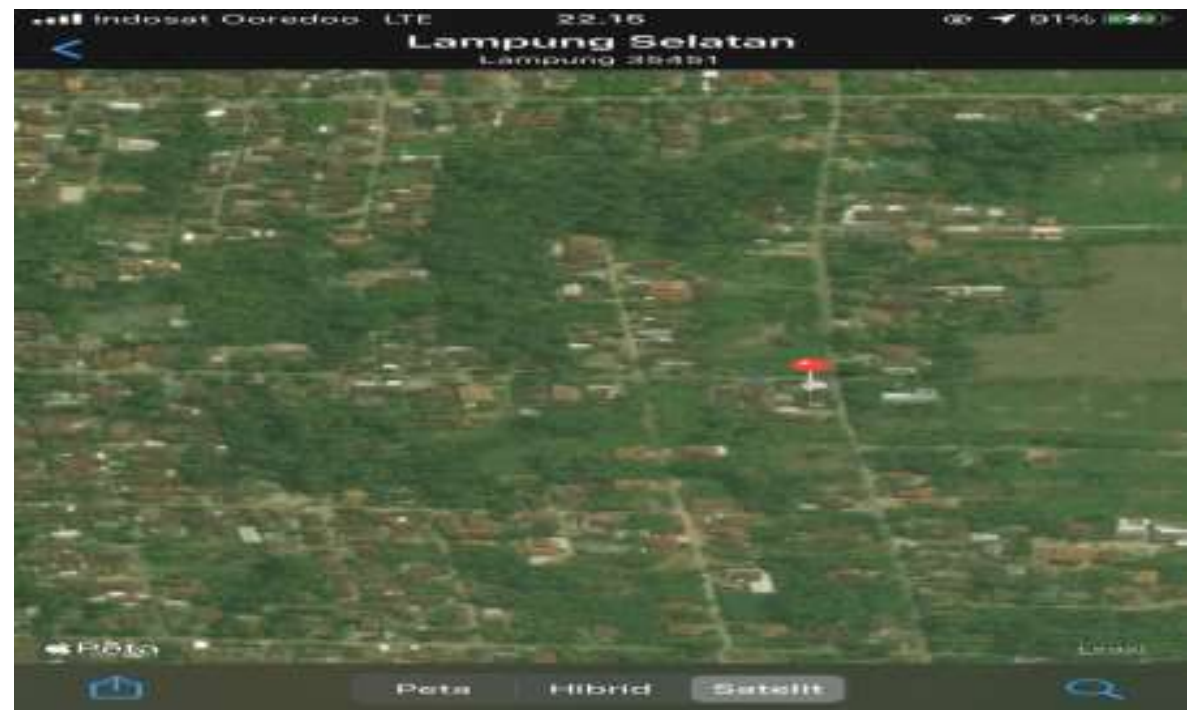

\section{METODE}

Kegiatan telah dilaksanakan pada hari Senin, 29 maret 2021 pukul 10.00 hingga selesai . Subjek dalam penelitian ini adalah lansia di desa hanura kec. Teluk pandan kab. Pesawaran. Kegiatan dilakukan dengan memberikan edukasi berupa penyuluhan dengan metode ceramah. Waktu yang diperlukan dalam penyampaian materi adalah 40 menit, Kegiatan dilakukan dengan memberikan edukasi berupa penyuluhan dengan tahapan yaitu memberikan materi tentang pentingnya pemahaman pemberian jus alpukat dan madu untuk menurunkan tekanan darah pada lansia penderita hipertensi,. Penyuluhan diberikan dengan metode ceramah. Waktu yang diperlukan dalam penyampaian materi adalah 40 menit. Tahap akhir dari kegiatan tersebut adalah mengukur kembali tingkat pengetahuan lansia dengan memberikanpertanyaan diberikan secara lisan.

\section{HASIL \& PEMBAHASAN}

Rangkaian kegiatan penyuluhan kepada lansia di Desa Hanura Kec.Teluk Pandan Kab.Pesawaran berjalan dengan lancar tanpa kendala.Penyuluhan di ikuti 10 peserta yang terdiri dari lansia, kader serta bidan. Peserta cukup antusias terhadap materi yang diberikan.Umpan balik yang di berikan pun cukup positif. Terdapat beberapa pertanyaan dan sanggahan dari peserta penyuluhan terkait materi.Materi penyuluhan dapat diterima dengan baik. 


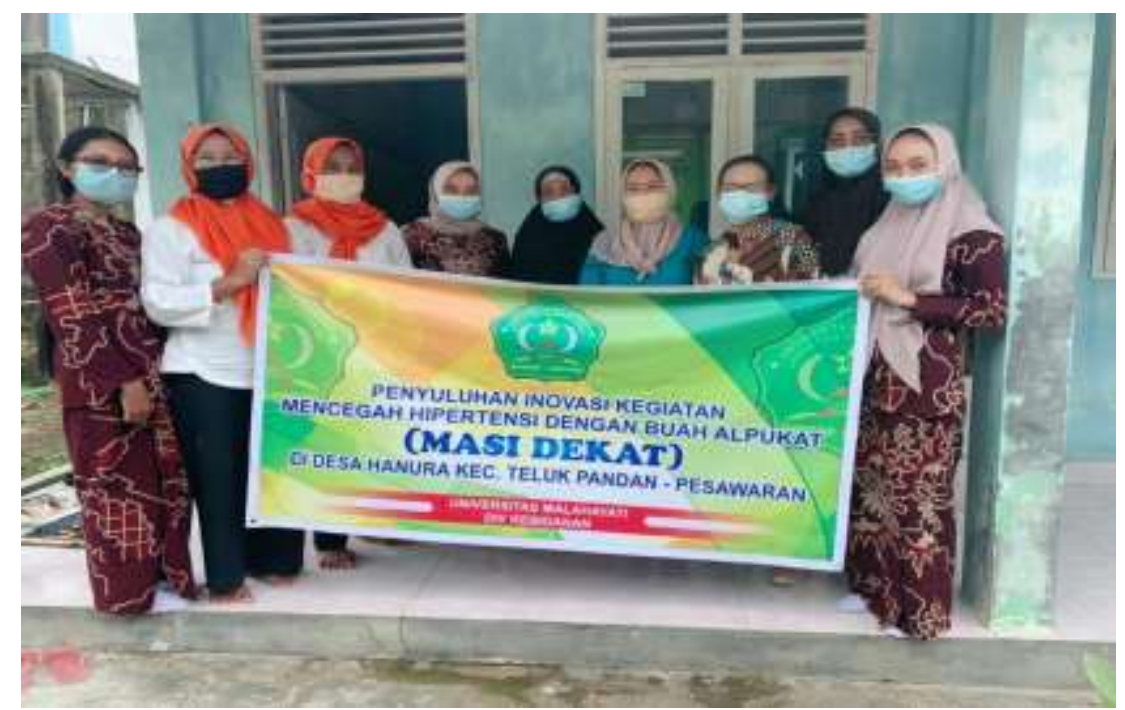

\section{KESIMPULAN}

Kesimpulan dari kegiatan penyuluhan di Desa Hanura Kec. Teluk pandan kab. Pesawaran adalah Adanya peningkatan pengetahuan lansia terhadap pemberian jus alpukat dan madu untuk menurunkan tekanan darah pada lansia penderita hipertensi.

\section{DAFTAR PUSTAKA}

Grey, et al., 2005. Lecture Notes Kardiologi, Edisi keempat, Erlangga, Jakarta.

Kementrian Kesehatan RI, 2010. Hipertensi Penyebab Kematian Nomor tiga.

Notoadmojdo, S., 2003. Ilmu Kesehatan Masyrakat, Rineka Cipta, Jakarta.

Pfizer Indonesia, 2007. Mengapa Hipertensi dan Hiperkolestrol Harus di obati.

Jiandita, M., \& Anita, D. C. (2011). Pengaruh Pemberian Jus Alpukat dan Madu terhadap Penurunan Tekanan Darah pada Lansia Penderita Hipertensi di Posyandu Edelweis Dusun Serut Palbapang Bantul Yogyakarta (Doctoral dissertation, STIKES'Aisyiyah Yogyakarta).

Evizar, E., Astriana, A., Yuviska, I. A., \& Sunarsih, S. (2021). PEMBERIAN JUS SEMANGKA TERHADAP PENURUNAN TEKANAN DARAH PADA WANITA USIA SUBUR. MIDWIFERY JOURNAL, 1(3), 135-139.

Mariza, A., Astriana, A., Yuviska, I. A., Azhari, D., Mustilah, F., Apridayanti, A., ... \& Kristina, N. (2021). INOVASI KEGIATAN "TAPE BUMILA (DUTA PEDULI IBU HAMIL ANEMIA)" DESA KALI BENING RAYA KECAMATAN ABUNG SELATAN KABUPATEN LAMPUNG UTARA. JURNAL PERAK MALAHAYATI, 3(1), 61-64. 